\title{
Liquid and Vapor Phase of Four Conifer-Derived Essential Oils: Comparison of Chemical Compositions and Antimicrobial and Antioxidant Properties
}

\author{
Stefania Garzoli ${ }^{1, *,+}+$ , Valentina Laghezza Masci ${ }^{2,+}{ }^{\circ}$, Valentina Caradonna ${ }^{2}$, Antonio Tiezzi ${ }^{2}$, \\ Pierluigi Giacomello ${ }^{1}$ (D) and Elisa Ovidi ${ }^{2}$ (D) \\ 1 Department of Drug Chemistry and Technology, Sapienza University, 00185 Rome, Italy; \\ pierluigi.giacomello@uniroma1.it \\ 2 Department for the Innovation in Biological, Agrofood and Forestal Systems, Tuscia University, \\ 01100 Viterbo, Italy; laghezzamasci@unitus.it (V.L.M.); valecarad@gmail.com (V.C.); antoniot@unitus.it (A.T.); \\ eovidi@unitus.it (E.O.) \\ * Correspondence: stefania.garzoli@uniroma1.it \\ + These authors contributed equally.
}

check for updates

Citation: Garzoli, S.; Masci, V.L.; Caradonna, V.; Tiezzi, A.; Giacomello, P.; Ovidi, E. Liquid and Vapor Phase of Four Conifer-Derived Essential Oils: Comparison of Chemical Compositions and Antimicrobial and Antioxidant Properties.

Pharmaceuticals 2021, 14, 134.

https://doi.org/10.3390/ph14020134

Academic Editor: Fiorella Meneghetti; Daniela Barlocco

Received: 30 December 2020

Accepted: 4 February 2021

Published: 8 February 2021

Publisher's Note: MDPI stays neutral with regard to jurisdictional claims in published maps and institutional affiliations.

Copyright: (C) 2021 by the authors Licensee MDPI, Basel, Switzerland. This article is an open access article distributed under the terms and conditions of the Creative Commons Attribution (CC BY) license (https:// creativecommons.org/licenses/by/ $4.0 /)$.

\begin{abstract}
In this study, the chemical composition of the vapor and liquid phase of Pinus cembra L., Pinus mugo Turra, Picea abies L., and Abies Alba M. needles essential oils (EOs) was investigated by Headspace-Gas Chromatography/Mass Spectrometry (HS-GC/MS). In the examined EOs, a total of twenty-eight components were identified, most of which belong to the monoterpenes family. $\alpha$-Pinene (16.6-44.0\%), $\beta$-pinene (7.5-44.7\%), limonene (9.5-32.5\%), and $\gamma$-terpinene (0.3-19.7\%) were the most abundant components of the liquid phase. Such major compounds were also detected in the vapor phase of all EOs, and $\alpha$-pinene reached higher relative percentages than in the liquid phase. Then, both the liquid and vapor phases were evaluated in terms of antibacterial activity against three Gramnegative bacteria (Escherichia coli, Pseudomonas fluorescens, and Acinetobacter bohemicus) and two Grampositive bacteria (Kocuria marina and Bacillus cereus) using a microwell dilution assay, disc diffusion assay, and vapor phase test. The lowest Minimum Inhibitory Concentration (MIC) $(13.28 \mathrm{mg} / \mathrm{mL})$ and Minimal Bactericidal Concentration (MBC) $(26.56 \mathrm{mg} / \mathrm{mL})$ values, which correspond to the highest antibacterial activities, were reported for $P$. abies $\mathrm{EO}$ against $A$. bohemicus and for $A$. alba EO against $A$. bohemicus and $B$. cereus. The vapor phase of all the tested EOs was more active than liquid phase, showing the inhibition halos from $41.00 \pm 10.15 \mathrm{~mm}$ to $80.00 \pm 0.00 \mathrm{~mm}$ for three bacterial strains (A. bohemicus, K. marina, and B. cereus). Furthermore, antioxidant activities were also investigated by 2,2-diphenyl-1-picrylhydrazyl (DPPH) and 2,2'-azinobis (3- ethylbenzothiazoline-6sulfonic acid) diammonium salt (ABTS) assays, and a concentration-dependent antioxidant capacity for all EOs was found. P. mugo EO showed the best antioxidant activity than the other Pinaceae EOs. The four Pinaceae EOs could be further investigated for their promising antibacterial and antioxidant properties, and, in particular, $\alpha$-pinene seems to have interesting possibilities for use as a novel natural antibacterial agent.
\end{abstract}

Keywords: Pinus cembra L.; Pinus mugo Turra; Picea abies L.; Abies alba M.; essential oil; chemical investigation; HS-GC/MS; antibacterial activity; antioxidant activity

\section{Introduction}

Since ancient times, plants are a source of different kinds of compounds that humans used for their numerous biological activities and as a source for drug development [1] Nowadays, the studies on antioxidant and antimicrobial activities of natural products are of considerable interest due to the importance of identifying and characterizing new bioactive molecules for applications in different fields as food preservation and packaging, antibiotically resistance phenomenon, and plant diseases. 
Among plant secondary metabolites, essential oils (EOs), biosynthesized by glandular trichomes and other secretory structures in plants, are liquids particularly rich in volatile molecules such as monoterpene and sesquiterpene hydrocarbons, oxygenated monoterpenes and sesquiterpenes, esters, aldehydes, ketones, alcohols, phenols, and oxides [2-4]. The chemical composition of EOs can vary from plant to plant and even in the same species and depends on several factors such as post-harvest conservation conditions [5], extraction methods [6-8] and times $[9,10]$, microclimate, and site in which the plant is growing [11,12]. EOs contribute to the plant relations with environment and with other organisms, and humans and animals take advantage of the abundance of such bioactive molecules from the plant kingdom [4]. Numerous papers deal with the biological activities of the EOs such as antioxidant and anti-inflammatory properties, antibacterial and antifungal activities, immunomodulatory effects, and cytotoxic activities against different cancer cell lines [13-19]. Gymnosperms, the Cupressaceae, and the Pinaceae families produce economically important EOs [20]. The Pinaceae family is the largest family of non-flowering seed plants and comprises 11 genera and approximately 230 species of trees, rarely shrubs, which are widely distributed in the Northern Hemisphere [21,22]. The biological activities of Pinaceae EOs reflect the richness in their chemical composition. Antioxidant, antibacterial, antifungal, insect larvicidal, anti-inflammatory, and antiproliferative activities are reported for different genus of the Pinaceae family [16,23-30].

In our searching and studying of natural compounds, in the present paper, we investigated and compared the chemical composition and the antimicrobial and antioxidant properties of the vapor and liquid phase of four Pinaceae EOs from Pinus cembra L. and Pinus mugo Turra, which belong to the Pinus genus, and Picea abies L. and Abies alba M., which belong to the Picea and Abies genus, respectively.

\section{Results}

\subsection{Liquid and Vapor Phases EOs Chemical Composition}

By Gas Chromatography-Mass Spectrometry (GC/MS) and Headspace (HS)-GC/MS analysis, the composition of the vapor and liquid phase of all EOs was described. Twenty components were identified in P. cembra and P. mugo EOs, and they are listed in Table 1. The most abundant component was $\alpha$-pinene ( $44.0 \%$ when using GC/MS and $65.6 \%$ when using HS/GC-MS) followed by $\gamma$-terpinene (19.7\% GC/MS; $11.0 \%$ HS/GC-MS), limonene (14.8\% GC/MS and 8.2\%; HS/GC-MS) and $\beta$-pinene (12.5\% GC/MS; $12.4 \%$ HS/GC-MS) in P. cembra EO. On the contrary, $\beta$-pinene (43.3\% GC/MS; $42.3 \%$ HS/GC-MS) was the major compound in P. mugo. EO followed by $\alpha$-pinene (16.6\% GC/MS; $31.6 \%$ HS/GC-MS) and limonene (9.5\% GC/MS; 7.8\% HS/GC-MS). $\beta$-Phellandrene (16.0\%) as well as other minor compounds such as p-cymenene $(0.1 \%)$, copaene $(0.1 \%)$, and bornyl acetate $(3.0 \%)$ appeared only in the liquid phase of P. mugo EO. On the other hand, $\alpha$-phellandrene $(0.7 \%)$ was detected only in P. mugo vapor phase EO. In particular, in the vapor phase of both EOs, the components from $\mathrm{N}^{\circ} 11$ to $\mathrm{N}^{\circ} 20$ were missing except for $\beta$-caryophyllene $(0.1 \%)$, which was detected in P. mugo EO.

Twenty-one components were identified in P. abies and A. alba EOs, and they are listed in Table 2. $\beta$-Pinene was the principal compound in P. abies EO ( $20.2 \%$ when using GC/MS and $34.5 \%$ when using HS/GC-MS), while $\alpha$-pinene (30.8\% GC/MS; $51.3 \%$ HS/GC-MS) was the principal compound in P. abies EO. The second most abundant component was $\alpha$-pinene $(20.2 \%$ and $34.5 \%)$ in P. abies EO and limonene $(32.5 \%$ and $19.0 \%)$ in A. alba EO when using GC/MS and HS/GC-MS, respectively. p-Cymene $(0.2 \% ; 0.1 \%)$, camphor $(1.2 \% ; 0.2 \%)$, and borneol $(2.1 \% ; 0.2 \%)$ were detected only in the liquid and vapor phase, respectively of P. abies EOs. $\alpha$-Himachalene $(0.3 \%)$, citronellol acetate $(0.4 \%)$, humulene $(1.6 \%)$, and caryophyllene oxide (0.1) appeared only in the liquid phase of A. alba EO. Lastly, in the vapor phase of both EOs, the components from $\mathrm{N}^{\circ} 12$ to $\mathrm{N}^{\circ} 21$ were missing except for borneol $(0.2 \%)$, which was detected in P. abies EO. 
Table 1. Chemical composition (\%) of liquid and vapor phases of P. cembra and P. mugo EOs.

\begin{tabular}{|c|c|c|c|c|c|c|c|}
\hline $\mathbf{N}^{\circ}$ & COMPONENT $^{1}$ & $\mathrm{LRI}^{2}$ & $\mathrm{LRI}^{3}$ & $P_{c}(\%)^{4}$ & $P c(\%)^{5}$ & $\operatorname{Pm}(\%)^{6}$ & $\operatorname{Pm}(\%)^{7}$ \\
\hline 1 & $\alpha$-pinene & 1019 & 1021 & 44.0 & 65.6 & 16.6 & 31.6 \\
\hline 2 & camphene & 1062 & 1065 & 1.6 & 2.3 & 1.6 & 2.9 \\
\hline 3 & $\beta$-pinene & 1098 & 1099 & 12.5 & 12.4 & 43.3 & 42.3 \\
\hline 4 & $\beta$-thujene & 1120 & 1118 & 0.3 & 0.2 & 0.3 & - \\
\hline 5 & $\alpha$-phellandrene & 1158 & 1160 & - & - & - & 0.7 \\
\hline 6 & limonene & 1197 & 1198 & 14.8 & 8.2 & 9.5 & 7.8 \\
\hline 7 & $\beta$-phellandrene & 1210 & 1207 & - & - & 16.0 & - \\
\hline 8 & $\gamma$-terpinene & 1270 & 1241 & 19.7 & 11.0 & 0.3 & 13.3 \\
\hline 9 & p-cymene & 1270 & 1268 & 0.1 & $\operatorname{Tr}$ & 0.2 & 0.2 \\
\hline 10 & terpinolene & 1285 & 1282 & 0.5 & 0.2 & 2.1 & 1.1 \\
\hline 11 & p-cymenene & 1431 & 1435 & - & - & 0.1 & - \\
\hline 12 & copaene & 1491 & 1487 & - & - & 0.1 & - \\
\hline 13 & bornyl acetate & 1571 & 1567 & - & - & 3.0 & - \\
\hline 14 & thymol methyl ether & 1576 & 1575 & 1.2 & $\operatorname{tr}$ & - & - \\
\hline 15 & $\beta$-caryophyllene & 1620 & 1619 & 0.4 & - & 3.6 & 0.1 \\
\hline 16 & $\alpha$-terpineol & 1655 & 1655 & 0.2 & - & 0.2 & $\operatorname{tr}$ \\
\hline 17 & humulene & 1670 & 1667 & 0.5 & - & 1.1 & - \\
\hline 18 & $\gamma$-muurolene & 1674 & 1673 & 0.4 & - & 0.3 & - \\
\hline 19 & $\alpha$-muurolene & 1691 & 1690 & 2.4 & - & 0.9 & - \\
\hline \multirow[t]{5}{*}{20} & $\delta$-cadinene & 1760 & 1758 & 1.4 & - & 0.5 & - \\
\hline & SUM & & & 100.0 & 99.9 & 99.7 & 100.0 \\
\hline & Monoterpenes & & & 93.7 & 99.9 & 93.2 & 100.0 \\
\hline & Sesquiterpenes & & & 5.1 & - & 6.5 & - \\
\hline & Other & & & 1.2 & - & - & - \\
\hline
\end{tabular}

${ }^{1}$ The components are reported according their elution order on a polar column; ${ }^{2}$ Linear retention indices measured on polar column; ${ }^{3}$ Linear retention indices from the literature; ${ }^{4}$ Percentage values of $P$. cembra EO components $(\%) ;{ }^{5}$ Percentage values of $P$. cembra EO components (vapor phase); ${ }^{6}$ Percentage mean values of $P$. mugo EO components $(\%) ;{ }^{7}$ Percentage mean values of $P$. mugo EO components (vapor phase); -Not detected; tr: traces (mean value $<0.1 \%$ ).

Table 2. Chemical composition (\%) of liquid and vapor phases of P. abies and A. alba essential oils (EOs).

\begin{tabular}{|c|c|c|c|c|c|c|c|}
\hline $\mathbf{N}^{\circ}$ & COMPONENT $^{1}$ & $\mathrm{LRI}^{2}$ & LRI $^{3}$ & $\operatorname{Pa}(\%)^{4}$ & $\operatorname{Pa}(\%)^{5}$ & $A a(\%)^{6}$ & $A a(\%)^{7}$ \\
\hline 1 & santene & 980 & 984 & 0.7 & 1.9 & 1.4 & 4.2 \\
\hline 2 & $\alpha$-pinene & 1019 & 1021 & 20.2 & 34.5 & 30.8 & 51.3 \\
\hline 3 & camphene & 1062 & 1065 & 7.2 & 10.5 & 11.2 & 16.5 \\
\hline 4 & $\beta$-pinene & 1098 & 1099 & 44.7 & 43.8 & 7.5 & 7.3 \\
\hline 5 & limonene & 1197 & 1198 & 14.2 & 8.0 & 32.5 & 19.0 \\
\hline 6 & $\gamma$-terpinene & 1240 & 1241 & 0.3 & 0.1 & 1.1 & 1.2 \\
\hline 7 & p-cymene & 1270 & 1268 & 0.2 & 0.1 & - & - \\
\hline 8 & terpinolene & 1285 & 1282 & 0.6 & 0.2 & 0.5 & 0.1 \\
\hline 9 & $\alpha$-longipinene & 1480 & 1477 & 0.3 & - & 0.9 & - \\
\hline 10 & camphor & 1506 & 1507 & 1.2 & 0.2 & - & - \\
\hline 11 & bornyl acetate & 1571 & 1567 & 3.7 & 0.3 & 4.2 & 0.4 \\
\hline 12 & longifolene & 1585 & 1583 & 1.1 & - & 0.6 & - \\
\hline 13 & $\beta$-caryophyllene & 1620 & 1619 & 1.3 & - & 5.8 & - \\
\hline 14 & $\alpha$-himachalene & 1641 & 1637 & - & - & 0.3 & - \\
\hline 15 & citronellol acetate & 1646 & 1644 & - & - & 0.4 & - \\
\hline 16 & $\alpha$-terpineol & 1655 & 1655 & 0.4 & $\operatorname{tr}$ & 0.2 & - \\
\hline 17 & humulene & 1670 & 1667 & - & - & 1.6 & - \\
\hline 18 & $\gamma$-muurolene & 1674 & 1673 & 0.4 & - & 0.3 & - \\
\hline 19 & borneol & 1677 & 1675 & 2.1 & 0.2 & - & - \\
\hline 20 & $\delta$-cadinene & 1760 & 1758 & 0.9 & - & 0.6 & - \\
\hline \multirow[t]{5}{*}{21} & caryophyllene oxide & 1895 & 1892 & - & - & 0.1 & - \\
\hline & SUM & & & 99.5 & 99.8 & 100.0 & 100.0 \\
\hline & Monoterpenes & & & 94.8 & 97.9 & 88.4 & 95.8 \\
\hline & Sesquiterpenes & & & 4.0 & 0.2 & 9.9 & - \\
\hline & Other & & & 0.7 & 1.9 & 1.7 & 4.2 \\
\hline
\end{tabular}

1 The components are reported according their elution order on polar column; ${ }^{2}$ Linear retention indices measured on polar column; ${ }^{3}$ Linear retention indices from the literature; ${ }^{4}$ Percentage mean values of $P$. abies EO components (\%); ${ }^{5}$ Percentage mean values of $P$. abies EO components (vapor phase); ${ }^{6}$ Percentage mean values of $A$. alba EO components (\%); ${ }^{7}$ Percentage mean values of $A$. alba EO components (vapor phase); -Not detected; tr: traces (mean value $<0.1 \%$ ).

Among the most abundant compounds, particular attention was paid to $\alpha$-pinene, as it always reached higher percentages in the vapor phase than in the liquid phase of the investigated EOs. The compared values are as follows: (44.0\% vs. $65.6 \%),(16.6 \%$ vs. $31.6 \%)$, 
(20.2\% vs. $35.5 \%)$, and (30.8\% vs. $51.3 \%$ ) liquid and vapor phase in P. cembra, P. mugo, $P$. abies, and $A$. alba EOs, respectively (Figure 1).

$\alpha$-pinene (\%) trend

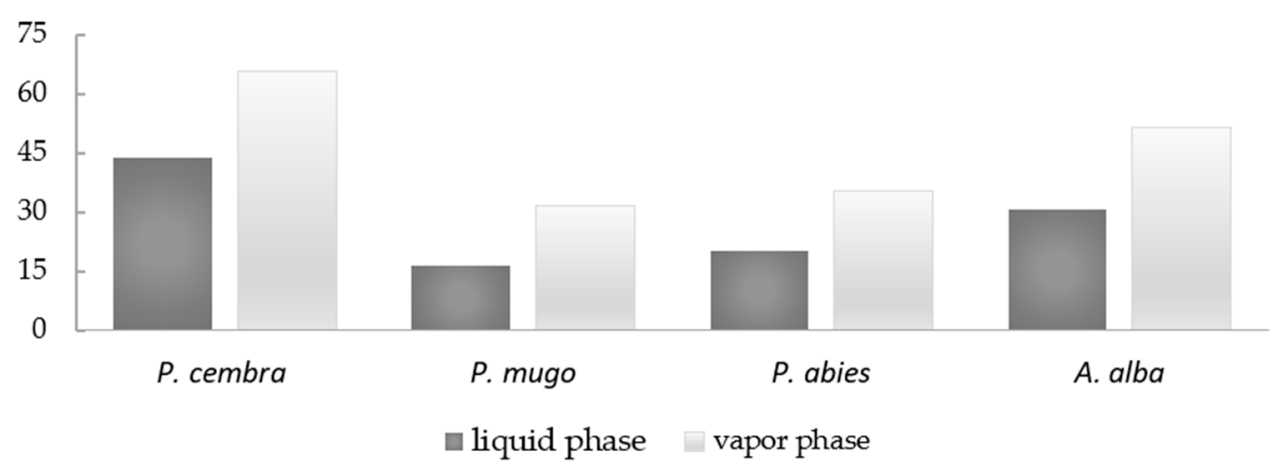

Figure 1. Bar graph of $\alpha$-pinene percentage trend in liquid and vapor phase EOs.

\subsection{Antibacterial Activities of P. Cembra, P. Mughus, P. Abies, and A. Alba EOs}

The antibacterial activities of the Pinaceae EOs were evaluated for three Gram-negative (Escherichia coli, Pseudomonas fluorescens, and Acinetobacter bohemicus) and two Gram-positive bacteria (Kocuria marina and Bacillus cereus using micro dilution assay to determine Minimum Inhibitory Concentration (MIC) and the Minimal Bactericidal Concentration (MBC), and the $\mathrm{MBC} / \mathrm{MIC}$ ratio defines an agent as bacteriostatic when the $\mathrm{MBC} / \mathrm{MIC}$ ratio $>4$ and as bactericidal when the $\mathrm{MBC} / \mathrm{MIC}$ ratio $\leq 4$ [31]. Furthermore, the disc diffusion assay by contact with the essential oil determined the diameter of bacterial growth inhibition zone (IZ), and the vapor phase test determined the antibacterial growth inhibition zone (Vapor IZ) by more volatile molecules of the EO in a preservative atmosphere. The antibacterial results of the tested EOs are summarized in Tables 3-6 reporting the MIC, $\mathrm{MBC}, \mathrm{MBC} / \mathrm{MIC}$ ratio, IZ, and vapor IZ following the treatments for each bacterial strain. In Table 3, the treatment with P. cembra EO showed MIC and MBC values of $53.12 \mathrm{mg} / \mathrm{mL}$ for E. coli, P. fluorescens, and K. marina, while MIC values were $26.56 \mathrm{mg} / \mathrm{mL}$ for $A$. bohemicus and B. cereus, and MBC values were $26.56 \mathrm{mg} / \mathrm{mL}$ and $53.12 \mathrm{mg} / \mathrm{mL}$, respectively. $\mathrm{MBC} / \mathrm{MIC}$ ratio defined the $P$. cembra $\mathrm{EO}$ as bactericidal against all bacterial strains. No effects were observed with the disc diffusion assay and with the vapor phase test for $P$. cembra EO against E. coli and P. fluorescens. The IZ and vapor IZ values were $17.67 \pm 0.58 \mathrm{~mm}$ and $67.33 \pm 2.52 \mathrm{~mm}$ for $A$. bohemicus, $9.33 \pm 0.58 \mathrm{~mm}$ and $80.00 \pm 0.00 \mathrm{~mm}$ for K. marina, and $11.67 \pm 1.15 \mathrm{~mm}$ and $80.00 \pm 0.00 \mathrm{~mm}$ for $B$. cereus, respectively.

Table 3. Antibacterial activity of P. cembra EO.

\begin{tabular}{cccccc}
\hline & \multicolumn{5}{c}{ Pinus cembra } \\
\cline { 2 - 6 } Strains & MIC & MBC $^{\mathbf{2}}$ & $\begin{array}{c}\text { MBC/MIC } \\
\text { Ratio }\end{array}$ & IZ $^{3}$ & Vapor IZ $^{4}$ \\
\hline E. coli & 53.12 & 53.12 & 1 & 0.00 & 0.00 \\
P. fluorescens & 53.12 & 53.12 & 1 & 0.00 & 0.00 \\
A. bohemicus & 26.56 & 26.56 & 1 & $17.67 \pm 0.58$ & $67.33 \pm 2.52$ \\
K. marina & 53.12 & 53.12 & 1 & $9.33 \pm 0.58$ & $80.00 \pm 0.00$ \\
B. cereus & 26.56 & 53.12 & 2 & $11.67 \pm 1.15$ & $80.00 \pm 0.00$ \\
\hline
\end{tabular}

${ }^{1}$ Minimal Inhibitory Concentration expressed in $\mathrm{mg} / \mathrm{mL}$ of EO treatment; ${ }^{2}$ Minimal Bactericidal Concentration expressed in $\mathrm{mg} / \mathrm{mL}$ of EO treatment; ${ }^{3}$ Growth inhibition zone by disc diffusion assay expressed in $\mathrm{mm} ;{ }^{4}$ Growth inhibition zone by vapor phase test expressed in $\mathrm{mm}$. Values are expressed as means $\pm \mathrm{SD} . p<0.05$ from one-way analysis of variance test (ANOVA).

Table 4 summarizes the antibacterial tests for P. mugo EO. MIC and MBC values were $52.16 \mathrm{mg} / \mathrm{mL}$ for E. coli, P. fluorescens, and K. marina, while MIC and MBC values were $26.08 \mathrm{mg} / \mathrm{mL}$ for $A$. bohemicus and MIC and MBC values were $26.08 \mathrm{mg} / \mathrm{mL}$ and 
$52.16 \mathrm{mg} / \mathrm{mL}$ for $B$. cereus, respectively. The MBC/MIC ratio defined as bactericidal the $P$. mugo EO against all bacterial strains. No effects were observed by the disc diffusion assay and by the vapor phase test for P. cembra EO on P. fluorescens. P. mugo EO was not highly active against $E$. coli with an IZ value of $9.67 \pm 0.58 \mathrm{~mm}$, while no growth inhibition zone was observed by the vapor phase test. Higher antibacterial activity was observed for the other bacterial strains: IZ and vapor IZ values were $25.33 \pm 4.51 \mathrm{~mm}$ and $41.00 \pm 10.15 \mathrm{~mm}$ for A. bohemicus, $11.33 \pm 1.15 \mathrm{~mm}$ and $80.00 \pm 0.00 \mathrm{~mm}$ for $K$. marina, and $15.67 \pm 1.15 \mathrm{~mm}$ and $76.67 \pm 5.77 \mathrm{~mm}$ for $B$. cereus, respectively. The $P$. mugo EO vapor phase was more active than the liquid phase against $A$. bohemicus, K. marina, and B. cereus.

Table 4. Antibacterial activity of P. mugo EO.

\begin{tabular}{cccccc}
\hline & \multicolumn{5}{c}{ Pinus mugo } \\
\cline { 2 - 6 } Strains & MIC $^{\mathbf{1}}$ & MBC $^{2}$ & $\begin{array}{c}\text { MBC/MIC } \\
\text { Ratio }\end{array}$ & IZ $^{3}$ & Vapor IZ $^{4}$ \\
\hline E. coli & 52.16 & 52.16 & 1 & $9.67 \pm 0.58$ & 0.00 \\
P. fluorescens & 52.16 & 52.16 & 1 & 0.00 & 0.00 \\
A. bohemicus & 26.56 & 26.56 & 1 & $25.33 \pm 4.51$ & $41 \pm 10.15$ \\
K. marina & 52.16 & 52.16 & 1 & $11.33 \pm 1.15$ & $80.00 \pm 0.00$ \\
B. cereus & 26.56 & 52.16 & 2 & $15.67 \pm 1.15$ & $76.67 \pm 5.77$ \\
\hline
\end{tabular}

${ }^{1}$ Minimal Inhibitory Concentration expressed in $\mathrm{mg} / \mathrm{mL}$ of EO treatment; ${ }^{2}$ Minimal Bactericidal Concentration expressed in $\mathrm{mg} / \mathrm{mL}$ of EO treatment; ${ }^{3}$ Growth inhibition zone by disc diffusion assay expressed in $\mathrm{mm} ;{ }^{4}$ Growth inhibition zone by vapor phase test expressed in $\mathrm{mm}$. Values are expressed as means $\pm \mathrm{SD}$. $p<0.05$ from one-way analysis of variance test (ANOVA).

Table 5. Antibacterial activity of P. abies EO.

\begin{tabular}{cccccc}
\hline \multirow{2}{*}{ Strains/Origin } & \multicolumn{5}{c}{ Picea abies } \\
\cline { 2 - 6 } & MIC $^{\mathbf{1}}$ & MBC $^{2}$ & $\begin{array}{c}\text { MBC/MIC } \\
\text { Ratio }\end{array}$ & IZ $^{3}$ & Vapor IZ $^{4}$ \\
\hline E. coli & 53.12 & 53.12 & 1 & 0.00 & 0.00 \\
P. fluorescens & 53.12 & 53.12 & 1 & 0.00 & 0.00 \\
A. bohemicus & 13.28 & 26.56 & 2 & $18.67 \pm 1.53$ & $76.67 \pm 5.77$ \\
K. marina & 53.12 & 53.12 & 1 & $9.67 \pm 1.15$ & $80.00 \pm 0.00$ \\
B. cereus & 26.56 & 53.12 & 2 & $11.67 \pm 1.53$ & $80.00 \pm 0.00$ \\
\hline
\end{tabular}

${ }^{1}$ Minimal Inhibitory Concentration expressed in $\mathrm{mg} / \mathrm{mL}$ of EO treatment; ${ }^{2}$ Minimal Bactericidal Concentration expressed in $\mathrm{mg} / \mathrm{mL}$ of EO treatment; ${ }^{3}$ Growth inhibition zone by disc diffusion assay expressed in $\mathrm{mm} ;{ }^{4}$ Growth inhibition zone by vapor phase test expressed in $\mathrm{mm}$. Values are expressed as means \pm SD. $p<0.05$ from one-way analysis of variance test (ANOVA).

Table 6. Antibacterial activity of A. alba EO.

\begin{tabular}{cccccc}
\hline & \multicolumn{5}{c}{ Abies alba } \\
\cline { 2 - 6 } Strains/Origin & MIC $^{\mathbf{1}}$ & MBC $^{2}$ & $\begin{array}{c}\text { MBC/MIC } \\
\text { Ratio }\end{array}$ & IZ $^{3}$ & Vapor IZ $^{4}$ \\
\hline E. coli & 51.28 & 51.28 & 1 & 0.00 & 0.00 \\
P. fluorescens & 51.28 & 51.28 & 1 & 0.00 & 0.00 \\
A. bohemicus & 12.82 & 25.64 & 2 & $19.67 \pm 0.58$ & $80.00 \pm 00$ \\
K. marina & 51.28 & 51.28 & 1 & $7.67 \pm 1.15$ & $80.00 \pm 00$ \\
B. cereus & 12.82 & 25.64 & 2 & $15.00 \pm 2.65$ & $66.67 \pm 11.55$ \\
\hline
\end{tabular}

${ }^{1}$ Minimal Inhibitory Concentration expressed in $\mathrm{mg} / \mathrm{mL}$ of EO treatment; ${ }^{2}$ Minimal Bactericidal Concentration expressed in $\mathrm{mg} / \mathrm{mL}$ of EO treatment; ${ }^{3}$ Growth inhibition zone by disc diffusion assay expressed in $\mathrm{mm} ;{ }^{4}$ Growth inhibition zone by vapor phase test expressed in mm. Values are expressed as means \pm SD. $p<0.05$. $p<0.05$ from one-way analysis of variance test (ANOVA).

P. abies EO antibacterial activity is reported in Table 5. MIC and MBC values were $53.12 \mathrm{mg} / \mathrm{mL}$ for E. coli, P. fluorescens, and K. marina. For A. bohemicus, a lower MIC value was observed $(13.28 \mathrm{mg} / \mathrm{mL})$, whereas $\mathrm{MBC}$ was $26.56 \mathrm{mg} / \mathrm{mL}$. The antibacterial activity 
for B. cereus was $26.56 \mathrm{mg} / \mathrm{mL}$ and $53.12 \mathrm{mg} / \mathrm{mL}$ for the MIC and MBC values, respectively. As obtained by the $\mathrm{MBC} / \mathrm{MIC}$ ratio, $P$. abies $\mathrm{EO}$ was bactericidal against all bacterial strains. No effects were observed by the disc diffusion assay and by the vapor phase test for $P$. abies $\mathrm{EO}$ on $P$. fluorescens and E. coli. IZ and vapor IZ values were $18.67 \pm 1.53 \mathrm{~mm}$ and $76.67 \pm 5.77 \mathrm{~mm}$ for A. bohemicus, $9.67 \pm 1.15 \mathrm{~mm}$ and $80.00 \pm 0.00 \mathrm{~mm}$ for $K$. marina and $11.67 \pm 1.53 \mathrm{~mm}$ and $80.00 \pm 0.00 \mathrm{~mm}$ for $B$. cereus, respectively. The P. abies EO vapor phase was more active rather than the liquid phase against $A$. bohemicus, K. marina, and B. cereus.

The results for $A$. alba antibacterial activity are reported in Table 6. MIC and MBC values were $51.28 \mathrm{mg} / \mathrm{mL}$ for E. coli, P. fluorescens, and K. marina. Lower MIC and MBC values were found for $A$. bohemicus and for $B$. cereus $(12.82 \mathrm{mg} / \mathrm{mL}$ and $25.64 \mathrm{mg} / \mathrm{mL}$, respectively). The $\mathrm{MBC} / \mathrm{MIC}$ ratio defined as bactericidal the $A$. alba $\mathrm{EO}$ against all bacterial strains. No effects were observed in the disc diffusion assay and in the vapor phase test for A. alba $\mathrm{EO}$ on E. coli and P. fluorescens. Higher antibacterial activity was detected for the other bacterial strains: IZ and vapor IZ values were $19.67 \pm 0.58 \mathrm{~mm}$ and $80.00 \pm 00 \mathrm{~mm}$ for A. bohemicus, $7.67 \pm 1.15$ and $80.00 \pm 0.00$ for K. marina, and $15.00 \pm 2.65$ and $66.67 \pm 11.55$ for $B$. cereus, respectively. The vapor phase test revealed that the activities of the A. alba EO against $A$. bohemicus, K. marina, and B. cereus were higher than those of the liquid phase.

\subsection{Antioxidant Activity}

To determine the antioxidant activity of the four Pinaceae EOs, 2,2-Diphenyl-1picrylhydrazyl (DPPH) scavenging activity and 2,2'-azinobis (3- ethylbenzothiazoline6-sulfonic acid) diammonium salt (ABTS) radical scavenging assay, based on the reaction of the potential antioxidant with colored radicals, were carried out. The antioxidant activity results are reported in Table 7 . In all EOs, a concentration-dependent antioxidant capacity was found. In both tests, $P$. mugo EO showed the highest antioxidant activity than the other Pinaceae EOs. This EO exhibits lower $\mathrm{IC}_{50}$ values $(3.08 \mu \mathrm{g} / \mathrm{mL}$ and $43.08 \mu \mathrm{g} / \mathrm{mL}$ for DPPH and ABTS assays, respectively) and higher TEAC values $(7.65 \mathrm{~mol} / \mathrm{mg}$ and $14.01 \mathrm{~mol} / \mathrm{mg}$ for DPPH and ABTS assays, respectively). The second effective essential oil was the $A$. alba EO with $\mathrm{IC}_{50}$ values of $7.84 \mu \mathrm{g} / \mathrm{mL}$ and $44.23 \mu \mathrm{g} / \mathrm{mL}$ and TEAC values of $1.63 \mathrm{~mol} / \mathrm{mg}$ and $13.26 \mathrm{~mol} / \mathrm{mg}$ in the DPPH method and ABTS method, respectively. The TEAC values of $P$. cembra and $P$. abies EOs were almost identical: $1.63 \mathrm{~mol} / \mathrm{mg}$ and $1.68 \mathrm{~mol} / \mathrm{mg}$ in the DPPH assay, respectively and $13.26 \mathrm{~mol} / \mathrm{mg}$ for both the EOs in the ABTS assay. Taking into account the ABTS test, the $\mathrm{IC}_{50}$ amount was $44.90 \mu \mathrm{g} / \mathrm{mL}$ in $P$. cembra EO and $45.00 \mu \mathrm{g} / \mathrm{mL}$ in $A$. alba EO. In the DPPH test, both EOs showed similar $\mathrm{IC}_{50}$ values, too $(13.01 \mu \mathrm{g} / \mathrm{mL}$ for P. cembra and $13.05 \mu \mathrm{g} / \mathrm{mL}$ for P. abies $)$. A. alba EO remains the least effective in antioxidant capacity of the analyzed Pinaceae EOs.

Table 7. Effects of P. mugo, P. cembra, P. abies, and A. alba EOs in different antioxidant assays.

\begin{tabular}{cccccc}
\hline \multirow{2}{*}{ Assay } & $\begin{array}{c}\text { Values } \\
\text { Expressed as }\end{array}$ & P. cembra & P. mugo & P.abies & A. alba \\
\hline \multirow{2}{*}{ DPPH } & $\mathrm{IC}_{50}{ }^{*}$ & $13.01 \pm 0.86$ & $3.08 \pm 0.65$ & $13.05 \pm 3.09$ & $7.84 \pm 1.70$ \\
& $\mathrm{TEAC}^{* *}$ & $1.63 \pm 0.46$ & $7.65 \pm 1.33$ & $1.68 \pm 0.64$ & $3.01 \pm 0.48$ \\
\hline \multirow{2}{*}{ ABTS } & $\mathrm{IC}_{50}{ }^{*}$ & $44.90 \pm 2.06$ & $43.08 \pm 6.95$ & $45.00 \pm 6.26$ & $44.23 \pm 1.10$ \\
& $\mathrm{TEAC}^{* *}$ & $13.26 \pm 1.45$ & $14.01 \pm 2.01$ & $13.26 \pm 0.52$ & $13.65 \pm 0.49$ \\
\hline
\end{tabular}

${ }^{*} \mu \mathrm{g} / \mathrm{mL}$ of essential oil; ${ }^{* *} \mu \mathrm{M}$ of Trolox equivalent/mg of essential oil. Values are expressed as means $\pm \mathrm{SD}$. $p<0.05$.

\section{Discussion}

The chemical profile of both the vapor and liquid phase and the antibacterial and antioxidant activities of four Pinaceae EOs, obtained from needles by steam distillation, were investigated using different kinds of techniques and assays. In the literature, a few papers reporting the Pinaceae EOs chemical composition are present, and no report describes the volatile composition of the vapor phase of the conifer-derived EOs by HS-GC/MS, as we 
applied for our investigation. In our investigations, the chemical constituents resulted primarily monoterpenoids and their contents were higher in the vapor phases of $P$. cembra (99.9\%) and P. mugo (100.0\%) EOs than the vapor phases of the P. abies $(97.9 \%)$ and A. alba $(95.8 \%)$ EOs. The major compounds of the P. cembra EO were $\alpha$-pinene $(44.0 \%), \gamma$-terpinene $(19.7 \%)$, limonene $(14.8 \%)$, and $\beta$-pinene $(12.5 \%)$. Similar composition was described by Lis et al. [32], where the needle oil was dominated by $\alpha$-pinene $(48.4 \%)$, limonene $(7.5 \%)$, and $\beta$-phellanderene (3.1\%); $\alpha$-pinene was also the major component (69.14\%) in needle EO of P. cembra growing in Romania [33]. The composition of the EO from twig tips with needles of the P. cembra L. growing in Salzburg Alps was represented by $\alpha$-pinene (43.9-48.3\%), $\beta$-phellandrene (13.1-17.2\%), and $\beta$-pinene (6.6-9.3\%) [34]. Pinus cembra needles EO from Slovakia consisted of $\alpha$-pinene (53.2\%), limonene (11.4\%), and $\beta$-phellandrene (9.4\%) [35].

The main components of $P$. mugo EO were $\beta$-pinene $(43.3 \%), \alpha$-pinene $(16.6 \%), \beta$ phellandrene $(16.0 \%)$, and limonene $(9.5 \%)$ with a low percentage of $\beta$-caryophyllene (3.6\%). A different composition was reported for P. mugo EO from needles growing in Poland where 3 -carene $(23.8 \%)$, myrcene $(22.3 \%)$, and $\alpha$-pinene $(10.3 \%)$ resulted as the main components [36]. 3-Carene (31.73\%) was also the major compound in EO of P. mugo from Kosovo [37], followed by $\alpha$-pinene (19.95\%) and $\beta$-phellandrene (13.49\%). P.mugo needles EOs from Macedonian [38] and Serbia [39] mainly consisted of $\Delta^{3}$-carene (amount up to $35 \%$ and $23.9 \%$ ), $\alpha$ - and $\beta$-pinene (up to $20 \%$ and $17.9 \%$ ) and $\beta$-phellandrene (amount about $15 \%$ and $7.2 \%$ ), respectively.

In $P$. abies EO, we found $\beta$-pinene $(44.7 \%)$ as the most abundant component followed by $\alpha$-pinene $(20.2 \%)$, limonene (14.2\%), and camphene (7.2\%). A different composition has been described for the EOs from shoots of P. abies that grow wild in different locations of Romania, which are characterized by limonene (from $6.27 \%$ up to $12.98 \%$ ), camphene (from $3.89 \%$ up to $14.07 \%$ ), $\alpha$-pinene (from $2.44 \%$ up to $10.42 \%$ ), and $\beta$-myrcene (from $0.44 \%$ up to $10.12 \%$ ) [40].

The chemical composition of $A$. alba EO showed two components such as limonene and $\alpha$-pinene with a similar percentage $(32.5 \%$ and $30.8 \%)$ followed by camphene $(11.2 \%)$ and $\beta$-pinene $(7.5 \%)$. The same compounds were listed with an inverted trend in $A$. alba EO from Montenegro where $\beta$-pinene $(32.8 \%)$ was the major component followed by $\alpha$-pinene (17.3\%) and camphene (16.7\%) [41]. On the contrary, $\alpha$-limonene (about 70\%) and $\alpha$-pinene (57\%) were the major compounds in A. alba EO from seeds and cones respectively [42]. In A. alba EO from Poland, limonene was the component with the higher percentage (82.9\%) detected in seed EO, whereas $\alpha$-pinene (50.0\%) was the main component in cone EO [43]. According to the literature [44] and on the basis of the reported data, it becomes evident that the chemical composition of the EOs from species belonging to the Pinaceae family can depend by multiple factors such as part of the plant examined, its geographic origin, and also, extraction methods and storage [45].

MIC and MBC values defined by the microwell dilution method were tested against $E$. coli, P. fluorescens and A. bohemicus Gram-negative bacteria strains and K. marina and B. cereus Gram-positive bacteria strains. The lowest MIC $(13.28 \mathrm{mg} / \mathrm{mL})$ and MBC $(26.56 \mathrm{mg} / \mathrm{mL})$ values, which correspond to the highest antibacterial activities, were reported for P. abies EO against $A$. bohemicus and for $A$. alba $\mathrm{EO}$ against $A$. bohemicus and $B$. cereus with $12.82 \mathrm{mg} / \mathrm{mL}$ (MIC) and $25.64 \mathrm{mg} / \mathrm{mL}(\mathrm{MBC})$.

The increase of antibiotically resistance phenomenon in human and animal pathologies has determined the intensification of research on new natural antimicrobial substances $[19,46,47]$, and in this view, several studies were carried out to investigate the biological activities of Pinaceae EOs and the roles of their molecules. P. abies EO extracted by supercritical carbon dioxide was investigated for antimicrobial properties on E. coli using the isothermal calorimetry technique, and it inhibited the growth and interfered with the metabolic activity of the microorganism [48]. Kartnig et al. [49] determined the antibacterial activities of the essential oils of young pine shoots on different bacterial strains also from human patients, and significant activities were revealed against $\mathrm{G}+$ bacteria strains and Candida species tested. Apetrei et al. [25] reported that needles and twigs 
essential oils of Pinus cembra showed high activity against Sarcina lutea and Staphylococcus aureus and no activity against B. cereus, E. coli and Pseudomonas aeruginosa.

The antibacterial activities of the four Pinaceae EOs were also confirmed by agar diffusion and disk volatilization methods by which the IZ and vapor IZ were measured in mm of inhibition halos. For all the tested EOs, the vapor phases were more active than the liquid phases, showing the inhibition halos from $41.00 \pm 10.15 \mathrm{~mm}$ to $80.00 \pm 0.00 \mathrm{~mm}$ for three bacterial strains (A. bohemicus, K. marina, and B. cereus). Concerning E. coli and $P$. fluorescens, a very low or null activity was reported. The results showed high activities of the EOs against A. bohemicus, K. marina, and B. cereus and a scarce or null activity against $E$. coli and $P$. fluorescens. The highest activities obtained by vapor phases of all EOs against $A$. bohemicus, K. marina, and B. cereus could be related with the presence of $\alpha$-pinene. In the graph bar (Figure 1), the relative percentages of $\alpha$-pinene were reported. It reached higher percentages in the vapor phase than in the liquid phase of all investigated EOs. In particular, liquid and vapor phase values were as follows: $(44.0 \%$ vs. $65.6 \%),(16.6 \%$ vs. $31.6 \%),(20.2 \%$ vs. $35.5 \%)$, and (30.8\% vs. $51.3 \%)$, in P. cembra, P. mugo, P. abies, and A. alba EOs respectively. These results suggest that $\alpha$-pinene could play an important role for the detected antibacterial activity. Some papers reported $\alpha$-pinene from Pinaceae EOs as the main compound showing good biological activity; it was the principal constituent $(5.2-37.0 \%)$ in five Moroccan Pinus species EOs [50] and in Pinus peuce Griseb. EOs (12.89-27.34\%) growing on three different locations in R. Macedonia [51].

Different studies confirmed the antibacterial properties of $\alpha$-pinene [52]. Freitas et al. [53] reported that $\alpha$-pinene has antibacterial and antibiotic-modulating activities against $S$. aureus; it also increases the activity of norfloxacin against $E$. coli and norfloxacin and gentamicin against $S$. aureus. Furthermore, Hippeli et al. [54] described an antiinflammatory potential of P. mugo EOs and its main compound $\alpha$-pinene, while Cole et al. [55] showed anti-proliferative activity on the MCF-7 cell line. On the other hand, Kurti et al. [37] attributed the antimicrobial activities of some Pinus species EOs from Kosovo to the hexane/diethyl ether fractions, which were mainly composed by oxygenated monoterpenes.

In the present study, the susceptibility of bacteria does not seem to be related with the features of the cell Gram-positive and Gram-negative bacteria wall structure, since the more sensitive bacteria strains, A. bohemicus, K. marina, and B. cereus do not belong to the same group. Generally, Gram-negative are more resistant than Gram-positive bacteria, because the cell wall does not allow the entrance into the cell of hydrophobic molecules present in the essential oils [56,57], although some exceptions have been shown [58,59]. In a comparative study of the essential oils from four Pinus species [30], it was found that the sensitivity of the tested bacterial pathogens cannot be related with the cell wall structure. Different mechanisms of action can explain the EOs antimicrobial activities, and their wide variety of molecular components can act at multiple levels [60].

The DPPH and ABTS assays demonstrated a significant antioxidant activity for all Pinaceae EOs. P. mugo EO was the more active with an $\mathrm{IC}_{50} 3.08 \pm 0.65$ and $43.08 \pm 6.95 \mu \mathrm{g} / \mathrm{mL}$ for DPPH and ABTS assays, respectively. The values expressed in Trolox equivalent (TEAC) confirmed identical results. A comparative investigation has been carried out on P. halepensis EO chemical composition and antioxidant activities, with respect to the impact of geographic variation and environmental conditions [61].

The variety of compounds that are present in the investigated EOs confers them numerous biological properties, and their antioxidant activities could be related to the presence of monoterpenes. Wang et al. [62] studied the antioxidant activities of seven terpenoids found in wine, and among the tested compounds, $\alpha$-pinene and limonene had the highest DPPH free radical scavenging and the highest reducing power. WojtunikKulesza [63] reviewed the monoterpenes biological properties and antioxidant activities of $\alpha$-pinene were also reported. 


\section{Materials and Methods}

\subsection{Materials}

P. cembra L., P. mugo Turra, A. alba M., and P. abies L. bio essential oils (IT BIO $013 n^{\circ}$ BZ-43509-AB) from needles growing in Alto Adige, Italy were obtained by steam distillation for $6 \mathrm{~h}$ extraction time and were directly provided by Bergila $\mathrm{GmbH} \mathrm{Srl}$ (Falzes/Issengo-Bolzano). Methanol, 2,2-Diphenyl-1-picrylhydrazyl (DPPH), 6-hydroxy2,5,7,8-tetramethylchroman-2-carboxylic acid (Trolox), 2,2'-azinobis (3-ethylbenzothiazoline6-sulfonic acid) diammonium salt (ABTS), potassium persulfate $\left(\mathrm{K}_{2} \mathrm{~S}_{2} \mathrm{O}_{8}\right)$, LB Broth with Agar and Thiazolyl Blue Tetrazolium Bromide (MTT) were from Sigma-Aldrich (Darmstadt, Germany). Gentamicin sulfate was purchased from Biochrom PAN-Bio-Tech GmbH (Aidenbach, Germany).

\subsection{Gas Chromatography-Mass Spectrometry (GC-MS) Analysis}

To describe the chemical composition of the EOs, a gas chromatograph with a flame ionization detector (FID) directly coupled to a mass spectrometer (MS) Perkin Elmer Clarus 500 model (Waltham, MA, USA) was used. The GC was equipped with a Restek Stabilwax (fused-silica) polar capillary column. Helium was used as carrier gas at a flow rate of $1 \mathrm{~mL} / \mathrm{min}$. The injector was set to a $280{ }^{\circ} \mathrm{C}$, and the oven temperature program was as follows: isothermal at $60{ }^{\circ} \mathrm{C}$ for $5 \mathrm{~min}$, then ramped to $220{ }^{\circ} \mathrm{C}$ at a rate of $6{ }^{\circ} \mathrm{C} \mathrm{min}-1$, and finally isothermal at $220^{\circ} \mathrm{C}$ for $20 \mathrm{~min}$. One $\mathrm{uL}$ of EO was diluted in $1 \mathrm{~mL}$ of methanol, and the injection volume was $1 \mu \mathrm{L}$. The Electron Impact-Mass Spectrometer (EI-MS) mass spectra were recorded at $70 \mathrm{eV}(\mathrm{EI})$ and were scanned in the range of $40-500 \mathrm{~m} / \mathrm{z}$. The ion source and the connection parts temperature was $220^{\circ} \mathrm{C}$. The injector split ratio was 1:20. The GC-TIC mass spectra were obtained by the TurboMass data analysis software (Perkin Elmer). The identification of components was performed by matching their mass spectra with those stored in the Wiley and NIST 02 mass spectra libraries database. Furthermore, the linear retention indices (LRIs) (relative to C8-C30 aliphatic hydrocarbons, injected in the column at the same operating conditions described above) were calculated and compared with available retention data present in the literature. The relative percentages of all identified components were obtained by peak area normalization from GC-FID chromatograms without the use of an internal standard or correction factors and expressed in percentages. All analyses were repeated twice.

\subsection{Headspace GC-MS Analysis}

The volatile chemical profile of essential oils was carried out with a Perkin Elmer Headspace Turbomatrix 40 (Waltham, MA, USA) autosampler connected to GC-MS [64,65]. One $\mathrm{mL}$ of the each EO was placed in $20 \mathrm{~mL}$ vials sealed with headspace PTFE-coated silicone rubber septa and caps. To optimize the headspace procedure for the determination of volatile organic compounds (VOCs), more operative parameters were optimized. The gas phase of the sealed vials was equilibrated for $20 \mathrm{~min}$ at $60^{\circ} \mathrm{C}$ and was followed immediately by compound desorption into GC injector in splitless mode. Quantification of compounds was performed by GC-FID in the same conditions described in the previous paragraph.

\subsection{Antibacterial Activities of the Pinaceae Essential Oils}

The antibacterial activities were investigated by using different methods, the Minimal Inhibitory Concentration (MIC), the Minimal Bactericidal Concentration (MBC), the agar diffusion method, and Vapor Phase Test (VPT).

\subsubsection{Bacterial Strains}

Five bacterial strains from the culture collections of the Plant Cytology and Biotechnology Laboratory of Tuscia University were tested to evaluate the antibacterial activities of P. cembra L., P. mugo Turra, A. alba M., and P. abies L. essential oils: Escherichia coli ATCC 25922, Pseudomonas fluorescens ATCC 13525, and Acinetobacter bohemicus DSM 102855 among Gram-negative and Kocuria marina DSM 16420 and Bacillus cereus ATCC 10876 among Gram- 
positive. All tested bacterial strains were maintained on LB broth (10 g tryptone, $5 \mathrm{~g}$ yeast extract, $10 \mathrm{~g} \mathrm{NaCl}$ per liter, autoclaved at $121^{\circ} \mathrm{C}$ for $20 \mathrm{~min}$ ) with agar. Bacteria cultures were maintained at two different temperatures: $26^{\circ} \mathrm{C}$ for $P$. fluorescens, A. bohemicus, and $B$. cereus and $37^{\circ} \mathrm{C}$ for K. marina and E. coli. All inocula were prepared with fresh cultures plated the day before the test.

\subsubsection{Minimum Inhibitory Concentration (MIC)}

The MIC is defined as the lowest concentration of antimicrobial agent that completely inhibits the growth of the microorganism as detected by the unaided eye and was carried out according to the microwell dilution method. Briefly, 12 dilutions of the four essential oils in LB broth (for P. cembra from 53.12 to $0.01 \mathrm{mg} / \mathrm{mL}$; for P. mugo from 52.16 to $0.01 \mathrm{mg} / \mathrm{mL}$; for $A$. alba form 51.28 to $0.01 \mathrm{mg} / \mathrm{mL}$ and for P. abies from 53.12 to $0.01 \mathrm{mg} / \mathrm{mL}$ ), a control with the same percentage of DMSO (from $6.25 \%$ to $0.003 \%$ ) in Lysogeny broth, a growth control without treatments, a positive control with gentamicin diluted from 100 to $0.05 \mu \mathrm{g} / \mathrm{mL}$, and a sterility control without bacteria were plated on 96 microwell plates. Then, $50 \mu \mathrm{L}$ of bacterial inoculum, $10^{6} \mathrm{CFU} / \mathrm{mL}$, were added in each well, except for the sterility control, and the plates were incubated for $24 \mathrm{~h}$ at the corresponding temperature. The visualization of the inhibition activity was obtained by $20 \mu \mathrm{L}$ of a solution of 3-(4,5-dimethylthiazol-2-yl)-2,5-diphenyltetrazolium bromide $(200 \mu \mathrm{g} / \mathrm{mL}$, MTT) added to each well. The assay was carried out in triplicate. The MBC/MIC ratio was reported to interpret the activity of the essential oil, and an antimicrobial agent is considered bacteriostatic when the ratio $\mathrm{MBC} / \mathrm{MIC}>4$ and bactericidal when the ratio $\mathrm{MBC} / \mathrm{MIC}$ is $\leq 4$ [31].

\subsubsection{Minimum Bactericidal Concentration (MBC)}

To verify the lowest concentration at which the tested essential oils kill the bacterial cells, which is defined the Minimum Bactericidal Concentration (MBC), $10 \mu \mathrm{L}$ of the last four dilutions from microwell dilution method in which no bacteria growth was observed were plated on a Petri plate with LB agar and incubated for $24 \mathrm{~h}$. The concentration at which no growth on agar was observed defined MBC values. The assay was carried out in triplicate.

\subsubsection{Agar Diffusion Method}

To determine the diameter of the halo inhibition of the bacteria growth induced by P. abies, A. alba, P. cembra, and P. mugo essential oils, the bacterial strains were suspended in LB broth to obtain a turbidity of $0.5 \mathrm{McF}$ arland (approximately $10^{8}$ Colony-Forming $\mathrm{Unit} / \mathrm{mL}-\mathrm{CFU} / \mathrm{mL}$ ) and then plated on LB broth with agar in a Petri plate. Sterile disks ( $6 \mathrm{~mm}$ diameter, Oxoid) were placed on the agar and impregnated with $10 \mu \mathrm{L}$ of samples. Two $\mu \mathrm{L}$ of gentamicin from a stock solution $(10 \mathrm{mg} / \mathrm{mL})$ was used as a positive control After $24 \mathrm{~h}$, the inhibitory activities of each essential oil were recorded as $\mathrm{mm}$ of halo diameter without growth [58] using a vernier caliper rule. The mean and the respective standard deviation (SD) of the measured halo in three independent experiments were recorded.

\subsubsection{Vapor Phase Test (VPT)}

The antibacterial activity of the Pinaceae essential oils in the vapor phase was evaluated by the modified disk volatilization method $[66,67]$. LB agar were poured into an $80 \mathrm{~mm}$ plastic Petri dish and a lower amount into its cover. Each bacterial suspension containing $10^{8} \mathrm{CFU} / \mathrm{mL}$ was plated on the LB agar medium. Then, $10 \mu \mathrm{L}$ of tested essential oils were added to a $6 \mathrm{~mm}$ sterile disk and placed on agar in the covered Petri plate. Liquid LB agar was put in the space between the cover and the base of the Petri dishes to facilitate the sealing and to prevent any vapor leakage. The Petri plates were incubated for $24 \mathrm{~h}$ in an inverted position, and afterwards, the inhibition halos were measured. Negative controls were carried out without the essential. All VPTs were carried out in triplicate. 


\subsection{Antioxidant Activity}

To assess the antioxidant activity of the four Pinaceae essential oils, DPPH radical scavenging activity and ABTS radical scavenging assay, which are based on the reaction of the potential antioxidant with colored radicals, were carried out.

\subsubsection{DPPH Scavenging Activity Assay}

In DPPH radical scavenging assay, the Pinaceae essential oils antioxidant activities were calculated against the 1,1-diphenyl-2-picrilidrazil radical (DPPH•) using the method described by Sanchez-Moreno et al. [68]. First, $100 \mu \mathrm{L}$ of fresh solution of a solid crystalline DPPH• $(0.2 \mathrm{mM})$ in methanol were added to $100 \mu \mathrm{L}$ of 12 geometric dilutions in methanol of each essential oil inside a 96-well plate. Geometric dilutions of the samples in methanol were used as sample blanks. In blank DPPH samples, essential oils were omitted. As a positive control, dilutions were prepared starting from Trolox solution $(1 \mathrm{mM})$ in methanol. The samples were incubated for $30 \mathrm{~min}$ in the dark at room temperature, and the absorbances decreases were measured at $517 \mathrm{~nm}$ using a Tecan Sunrise ${ }^{\mathrm{TM}} \mathrm{UV}$-vis spectrophotometer. The assay was repeated three times.

\subsubsection{ABTS Radical Scavenging Assay}

The radical scavenging activities of the Pinaceae essential oils were also calculated using the ABTS (2,2'-azino-bis (3-ethylbenzothiazoline-6-sulfonic acid) diammonium salt) assay described by Re et al. [69] with some modifications. The radical cation ABTS+ $\bullet$ was produced by reacting ABTS aqueous solution $(7 \mathrm{mM})$ with $\mathrm{K}_{2} \mathrm{~S}_{2} \mathrm{O}_{8}(140 \mathrm{mM})$ following an incubation for $16 \mathrm{~h}$ in the dark at room temperature before use. The ABTS+• solution was diluted with ethanol to reach an absorbance of $0.70 \pm 0.02$ at $734 \mathrm{~nm}$, and $1980 \mu \mathrm{L}$ was mixed with $20 \mu \mathrm{L}$ of the essential oil dilutions in ethanol. The resulting solutions were incubated for $5 \mathrm{~min}$ at room temperature. Afterwards, the absorbances were measured at $734 \mathrm{~nm}$ using a Jasco V-630 UV-Visible spectrophotometer and using Spectra Manager ${ }^{\mathrm{TM}}$ software. Furthermore, the absorbance of the ABTS+• blank, consisting of $20 \mu \mathrm{L}$ of ethanol dissolved in $1980 \mu \mathrm{L}$ of ABTS+• solution, was measured. The assay was repeated three times.

\subsection{3. $\mathrm{IC}_{50}$ and TEAC Calculation}

Trolox and samples calibration curves were obtained by plotting the inhibition ratio against sample concentrations. The inhibition ratio was calculated using the following formula:

$$
I R \%=\frac{\text { A blank }- \text { A sample }}{\text { A blank }} \times 100 .
$$

The IC50 parameter was calculated using the sample calibration curve. A lower value of the IC50 parameter correspond to a lower concentration of the EO that can scavenge 50\% of DPPH. molecules; therefore, it indicates a higher antioxidant activity.

The Trolox equivalent antioxidant capacity (TEAC) index was obtained from the ratio between the Trolox IC50 $(\mu \mathrm{M})$ and the sample IC50 $(\mathrm{mg} / \mathrm{L})$ :

$$
T E A C=\frac{I C_{50_{\text {trolox }}}}{I C_{50_{\text {sample }}}} .
$$

\subsection{Statistical Analysis}

The results were expressed as means \pm standard deviation (SD). The one-way analysis of variance test (ANOVA) using GraphPad Prism software (GraphPad Prism 5.0, GraphPad Software, Inc., San Diego, CA, USA) was used to evaluate statistical discrepancies between the groups ( $p$ values $<0.05$ ).

\section{Conclusions}

In this study, for the first time, the chemical composition of the liquid and vapor phase of four Pinaceae EOs was investigated by the HS-GC/MS technique. The results of analyses 
showed that these EOs are rich in monoterpenoids and highlight that $\alpha$-pinene, one of the main compounds, is more abundant in the vapor phase of each oil than in the liquid phase. The antimicrobial and antioxidant activities were also reported and compared. The vapor phase of each EO resulted more active against the investigated bacterial strains.

The biological effects of the Pinaceae EOs combined with their bioavailability makes them promising sources for possible application in different fields such as pharmacology, pharmacognosy, and phytochemistry.

Author Contributions: Conceptualization, S.G.; V.L.M.; E.O.; investigation, S.G., V.L.M.; V.C.; data curation, S.G.; V.L.M.; E.O.; writing—original draft preparation, S.G.; V.L.M.; E.O.; writing—review and editing, S.G.; A.T.; E.O.; supervision, P.G; A.T.; funding acquisition, P.G.; A.T. All the authors critically edited the manuscript before submission. All authors have read and agreed to the published version of the manuscript.

Funding: This research received no external funding.

Institutional Review Board Statement: Not applicable.

Informed Consent Statement: Not applicable.

Data Availability Statement: Not applicable.

Acknowledgments: The authors are thankful to Bergila, GmbH Srl (Falzes/Issengo-Bolzano) Italy, for providing Pinus cembra L., Pinus mugo Turra, Picea abies L. and Abies Alba M. essential oils.

Conflicts of Interest: The authors declare no conflict of interest.

\section{References}

1. Bernardini, S.; Tiezzi, A.; Masci, V.L.; Ovidi, E. Natural products for human health: An historical overview of the drug discovery approaches. Nat. Prod. Res. 2018, 32, 1926-1950. [CrossRef]

2. Tongnuanchan, P.; Benjakul, S. Essential Oils: Extraction, Bioactivities, and Their Uses for Food Preservation. J. Food Sci. 2014, 79, R1231-R1249. [CrossRef]

3. El Asbahani, A.; Miladi, K.; Badri, W.; Sala, M.; Addi, E.H.A.; Casabianca, H.; El Mousadik, A.; Hartmann, D.; Jilale, A.; Renaud, F.N.R.; et al. Essential oils: From extraction to encapsulation. Int. J. Pharm. 2015, 483, 220-243. [CrossRef]

4. Sharifi-Rad, J.; Sureda, A.; Tenore, G.C.; Daglia, M.; Sharifi-Rad, M.; Valussi, M.; Tundis, R.; Sharifi-Rad, M.; Loizzo, M.R.; Ademiluyi, A.O.; et al. Biological Activities of Essential Oils: From Plant Chemoecology to Traditional Healing Systems. Molecules 2017, 22, 70. [CrossRef]

5. Turek, C.; Stintzing, F.C. Stability of Essential Oils: A Review. Compr. Rev. Food Sci. Food Saf. 2013, 12, 40-53. [CrossRef]

6. Kamiie, Y.; Sagisaka, M.; Nagaki, M. Essential oil composition of Lavandula angustifolia "Hidcote": Comparison of hydrodistillation and supercritical fluid extraction methods. Trans. Mater. Res. Soc. Jpn. 2014, 39, 485-489. [CrossRef]

7. Chenni, M.; El Abed, D.; Rakotomanomana, N.; Fernandez, X.; Chemat, F. Comparative Study of Essential Oils Extracted from Egyptian Basil Leaves (Ocimum basilicum L.) Using Hydro-Distillation and Solvent-Free Microwave Extraction. Molecules 2016, 21, 113. [CrossRef] [PubMed]

8. Elyemni, M.; Louaste, B.; Nechad, I.; Elkamli, T.; Bouia, A.; Taleb, M.; Chaouch, M.; Eloutassi, N. Extraction of Essential Oils of Rosmarinus officinalis L. by Two Different Methods: Hydrodistillation and Microwave Assisted Hydrodistillation. Sci. World J. 2019, 2019, 3659432. [CrossRef]

9. Garzoli, S.; Božović, M.; Baldisserotto, A.; Sabatino, M.; Cesa, S.; Pepi, F.; Vicentini, C.B.; Manfredini, S.; Ragno, R. Essential oil extraction, chemical analysis and anti-Candida activity of Foeniculum vulgare Miller-new approaches. Nat. Prod. Res. 2017, 32, 1254-1259. [CrossRef]

10. Božović, M.; Garzoli, S.; Baldisserotto, A.; Romagnoli, C.; Pepi, F.; Cesa, S.; Vertuani, S.; Manfredini, S.; Ragno, R. Melissa officinalis L. subsp. altissima (Sibth. \& Sm.) Arcang. essential oil: Chemical composition and preliminary antimicrobial investigation of samples obtained at different harvesting periods and by fractionated extractions. Ind. Crop. Prod. 2018, 117, 317-321. [CrossRef]

11. Hendawy, S.; El Gendy, A.; Omer, E.; Pistelli, L.; Pistelli, L. Growth, Yield and Chemical Composition of Essential Oil of Mentha piperita var. multimentha Grown Under Different Agro-ecological Locations in Egypt. J. Essent. Oil Bear. Plants 2018, $21,23-39$. [CrossRef]

12. Chen, S.-X.; Yang, K.; Xiang, J.-Y.; Raymond Kwaku, O.; Han, J.-X.; Zhu, X.-A.; Huang, Y.-T.; Liu, L.-J.; Shen, S.-B.; Li, H.-Z.; et al. Comparison of Chemical Compositions of the Pepper EOs From Different Cultivars and Their AChE Inhibitory Activity. Nat. Prod. Commun. 2020, 15, 1934578X20971469.

13. Edris, A.E. Pharmaceutical and therapeutic Potentials of essential oils and their individual volatile constituents: A review. Phytother. Res. 2007, 21, 308-323. [CrossRef] 
14. Bakkali, F.; Averbeck, S.; Averbeck, D.; Idaomar, M. Biological effects of essential oils-a review. Food Chem. Toxicol. 2008, 46, 446-475. [CrossRef]

15. Elshafie, H.S.; Camele, I. An Overview of the Biological Effects of Some Mediterranean Essential Oils on Human Health. BioMed Res. Int. 2017, 2017, 9268468. [CrossRef]

16. Basholli-Salihu, M.; Schuster, R.; Hajdari, A.; Mulla, D.; Viernstein, H.; Mustafa, B.; Mueller, M. Phytochemical composition, anti-inflammatory activity and cytotoxic effects of essential oils from three Pinus spp. Pharm. Biol. 2017, 55, 1553-1560. [CrossRef]

17. de Lavor, É.M.; Fernandes, A.W.C.; de Andrade Teles, R.B.; Leal, A.E.B.P.; de Oliveira, R.G., Jr.; Silva, M.G.; de Oliveira, A.P.; Silva, J.C.; de Moura Fontes Araújo, M.T.; Coutinho, H.D.M.; et al. Essential Oils and Their Major Compounds in the Treatment of Chronic Inflammation: A Review of Antioxidant Potential in Preclinical Studies and Molecular Mechanisms. Oxidative Med. Cell. Longev. 2018, 2018, 1-23. [CrossRef] [PubMed]

18. Peterfalvi, A.; Miko, E.; Nagy, T.; Reger, B.; Simon, D.; Miseta, A.; Czéh, B.; Szereday, L. Much More Than a Pleasant Scent: A Review on Essential Oils Supporting the Immune System. Molecules 2019, 24, 4530. [CrossRef]

19. Wińska, K.; Mączka, W.; Łyczko, J.; Grabarczyk, M.; Czubaszek, A.; Szumny, A. Essential Oils as Antimicrobial Agents-Myth or Real Alternative? Molecules 2019, 24, 2130. [CrossRef]

20. Husnu Can Baser, K.; Buchbauer, G. Handbook of Essential Oils; Routledge: Milton Park, UK, 2015.

21. Ran, J.-H.; Shen, T.-T.; Wu, H.; Gong, X.; Wang, X.-Q. Phylogeny and evolutionary history of Pinaceae updated by transcriptomic analysis. Mol. Phylogenetics Evol. 2018, 129, 106-116. [CrossRef] [PubMed]

22. Simpson, M.G. Evolution and Diversity of Woody and Seed Plants. In Plant Systematics; Elsevier: New York, NY, USA, 2019; pp. 131-165.

23. Bağci, E.; Diğrak, M. Antimicrobial Activity of Essential Oils of someAbies (Fir) Species from Turkey. Flavour Fragr. J. 1996, 11, 251-256. [CrossRef]

24. Hong, E.-J.; Na, K.-J.; Choi, I.-G.; Choi, K.-C.; Jeung, E.-B. Antibacterial and Antifungal Effects of Essential Oils from Coniferous Trees. Biol. Pharm. Bull. 2004, 27, 863-866. [CrossRef] [PubMed]

25. Lungu, C.; Tuchilus, C.; Aprotosoaie, A.C.; Oprea, A.; Malterud, K.E.; Miron, A. Chemical, Antioxidant and Antimicrobial Investigations of Pinus cembra L. Bark and Needles. Molecules 2011, 16, 7773-7788. [CrossRef]

26. Politeo, O.; Skočibušić, M.; Maravić, A.; Ruscic, M.; Milos, M. Chemical Composition and Antimicrobial Activity of the Essential Oil of Endemic Dalmatian Black Pine (Pinus nigra ssp. dalmatica). Chem. Biodivers. 2011, 8, 540-547. [CrossRef]

27. Zeng, W.; Zhang, Z.; Gao, H.; Jia, L.-R.; He, Q. Chemical Composition, Antioxidant, and Antimicrobial Activities of Essential Oil from Pine Needle (Cedrus deodara). J. Food Sci. 2012, 77, C824-C829. [CrossRef]

28. Ismail, A.; Hanana, M.; Gargouri, S.; Jamoussi, B.; Hamrouni, L.; Amri, I. Comparative study of two coniferous species (Pinus pinaster Aiton and Cupressus sempervirens L. var. dupreziana [A. Camus] Silba) essential oils: Chemical composition and biological activity. Chil. J. Agric. Res. 2013, 73, 259-266. [CrossRef]

29. Xie, Q.; Liu, Z.; Li, Z. Chemical Composition and Antioxidant Activity of Essential Oil of Six Pinus Taxa Native to China. Molecules 2015, 20, 9380-9392. [CrossRef]

30. Mitić, Z.S.; Jovanović, B.; Jovanović, S.Č.; Mihajilov-Krstev, T.; Stojanović-Radić, Z.Z.; Cvetković, V.J.; Mitrović, T.L.; Marin, P.D.; Zlatković, B.; Stojanović, G.S. Comparative study of the essential oils of four Pinus species: Chemical composition, antimicrobial and insect larvicidal activity. Ind. Crop. Prod. 2018, 111, 55-62. [CrossRef]

31. Gatsing, D.; Tchakoute, V.; Ngamga, D.; Kuiate, J.; Tamokou, J.; Nji-Nkah, B.; Tchouanguep, F.; Fodouop, S. In vitro antibacterial activity of Crinum purpurascens Herb. leaf extract against the Salmonella species causing typhoid fever and its toxicological evaluation. Iran. J. Med. Sci. 2009, 34, 126-136.

32. Lis, A.; Kalinowska, A.; Krajewska, A.; Mellor, K. Chemical Composition of the Essential Oils from Different Morphological Parts of Pinus cembra L. Chem. Biodivers. 2017, 14, e1600345. [CrossRef] [PubMed]

33. Apetrei, C.L.; Spac, A.; Brebu, C.M.; Miron, A.; Popa, G. Composition and antioxidant and antimicrobial activities of the essential oils of a full-grown Pinus cembra L. tree from the Calimani Mountains (Romania). J. Serb. Chem. Soc. 2013, 78, 27-37. [CrossRef]

34. Chizzola, R.; Müllner, K. Variability of volatiles in Pinus cembra L. within and between trees from a stand in the Salzburg Alps (Austria) as assessed by essential oil and SPME analysis. Genet. Resour. Crop. Evol. 2020, 68, 567-579. [CrossRef]

35. Nikolić, B.; Todosijevićb, M.; Ratknića, M.; Đorđevićc, I.; Stankovićd, I.; Cvetkovićd, M.D.; Marine, P.; Teševićb, V. Terpenes and n-alkanes in needles of Pinus cembra. NPC 2018, 13, 1035-1037.

36. Lis, A.; Lukas, M.; Mellor, K. Comparison of Chemical Composition of the Essential Oils from Different Botanical Organs of Pinus mugo Growing in Poland. Chem. Biodivers. 2019, 16, e1900397. [CrossRef] [PubMed]

37. Kurti, F.; Giorgi, A.; Beretta, G.; Mustafa, B.; Gelmini, F.; Testa, C.; Angioletti, S.; Giupponi, L.; Zilio, E.; Pentimalli, D.; et al. Chemical composition, antioxidant and antimicrobial activities of essential oils of different Pinus species from Kosovo. J. Essent. Oil Res. 2019, 31, 263-275. [CrossRef]

38. Karapandzova, M.; Stefkov, G.; Karanfilova, I.C.; Panovska, T.K.; Stanoeva, I.P.; Stefova, M.; Kulevanova, S. Chemical Characterization and Antioxidant Activity of Mountain Pine (Pinus mugo Turra, Pinaceae) from Republic of Macedonia. Rec. Nat. Prod. 2019, 13, 50-63. [CrossRef]

39. Stevanovic, T.; Garneau, F.-X.; Jean, F.-I.; Vilotic, D.; Petrović, S.; Ruzic, N. The essential oil composition of Pinus mugo Turra from Serbia. Flavour Fragr. J. 2004, 20, 96-97. [CrossRef] 
40. Radulescu, V.; Saviuc, C.; Chifiriuc, C.; Oprea, E.; Ilies, D.C.; Marutescu, L.; Lazar, V. Chemical composition and antimicrobial activity of essential oil from shoots spruce (Picea abies L.). Rev. Chim. 2011, 62, 69-72.

41. Chalchat, J.-C.; Sidibé, L.; Maksimovic, Z.A.; Petrovic, S.D.; Gorunovic, M.S. Essential Oil of Abies alba Mill., Pinaceae, from the Pilot Production in Montenegro. J. Essent. Oil Res. 2001, 13, 288-289. [CrossRef]

42. Wajs, A.; Urbańska, J.; Zaleśkiewicz, E.; Bonikowski, R. Composition of Essential Oil from Seeds and Cones of Abies alba. Nat. Prod. Commun. 2010, 5, 1291-1294. [CrossRef]

43. Wajs-Bonikowska, A.; Sienkiewiczb, M.; Stobieckaa, A.; Macia, A.; Szokac, L.; Karna, E. Chemical Composition and Biological Activity of Abies alba and A. Koreana Seed and Cone Essential Oils and Characterization of Their Seed Hydrolates. Chem. Biodivers. 2015, 12, 407-418. [CrossRef]

44. Tümen, I.; Hafızoğlu, H.; Kilic, A.; Dönmez, I.E.; Sivrikaya, H.; Reunanen, M. Yields and Constituents of Essential Oil from Cones of Pinaceae spp. Natively Grown in Turkey. Molecules 2010, 15, 5797-5806. [CrossRef]

45. Sedláková, J.; Lojková, L.; Kubáň, V. Gas Chromatographic determination of monoterpenes in spruce needles (Picea abies, P. omorica, and P. pungens) after supercritical fluid extraction. Chem. Pap. 2003, 57, 359-363.

46. Pereira, R.L.; Pereira, A.M.; Ferreira, M.O.S.; Fontenelle, R.; Saker-Sampaio, S.S.; Santos, H.N.; Bandeira, P.A.; Vasconcelos, M.A.N.; Queiroz, J.; Braz-Filho, R.H.; et al. Evaluation of the antimicrobial and antioxidant activity of 7-hydroxy-4' ${ }^{\prime}$,6-dimethoxy-isoflavone and essential oil from Myroxylon peruiferum L.f. An. Acad. Bras. Ciências 2019, 91, e20180204. [CrossRef] [PubMed]

47. Donadu, M.G.; Le, N.T.; Ho, D.V.; Doan, T.Q.; Le, A.T.; Raal, A.; Usai, M.; Marchetti, M.; Sanna, G.; Madeddu, S.; et al. Phytochemical Compositions and Biological Activities of Essential Oils from the Leaves, Rhizomes and Whole Plant of Hornstedtia bella Škorničk. Antibiotics 2020, 9, 334. [CrossRef] [PubMed]

48. Haman, N.; Morozova, K.; Tonon, G.; Scampicchio, M.; Ferrentino, G. Antimicrobial Effect of Picea abies Extracts on E. coli Growth. Molecules 2019, 24, 4053. [CrossRef] [PubMed]

49. Kartnig, T.; Still, F.; Reinthaler, F. Antimicrobial activity of the essential oil of young pine shoots (Picea abies L.). J. Ethnopharmacol. 1991, 35, 155-157. [CrossRef]

50. Hmamouchi, M.; Hamamouchi, J.; Zouhdi, M.; Bessiere, J.M. Chemical and Antimicrobial Properties of Essential Oils of Five Moroccan Pinaceae. J. Essent. Oil Res. 2001, 13, 298-302. [CrossRef]

51. Karapandzova, M.; Stefkov, G.; Trajkovska-Dokic, E.; Kaftandzieva, A.; Kulevanova, S. Antimicrobial activity of needle essential oil of Pinus peuce Griseb. (Pinaceae) from Macedonian flora. Maced. Pharm. Bull. 2012, 57, 25-36. [CrossRef]

52. Da Silva, A.C.R.; Lopes, P.M.; De Azevedo, M.M.B.; Costa, D.C.M.; Alviano, C.S.; Alviano, D.S. Biological Activities of a-Pinene and $\beta$-Pinene Enantiomers. Molecules 2012, 17, 6305-6316. [CrossRef]

53. Freitas, P.R.; De Araújo, A.C.J.; Barbosa, C.R.D.S.; Muniz, D.F.; Da Silva, A.C.A.; Rocha, J.E.; Oliveira-Tintino, C.D.D.M.; RibeiroFilho, J.; Da Silva, L.E.; Confortin, C.; et al. GC-MS-FID and potentiation of the antibiotic activity of the essential oil of Baccharis reticulata (ruiz \& pav.) pers. and $\alpha$-pinene. Ind. Crop. Prod. 2020, 145, 112106. [CrossRef]

54. Hippeli, S.; Graßmann, J.; Vollmann, R.; Elstner, E.F. Latschenkieferöl: Möglicher Wirkmechanismus für antientzündliche Wirkung. Pharm. Zeitung. 2004, 149, 35-36.

55. Cole, R.A.; Bansal, A.; Moriarity, D.M.; Haber, W.A.; Setzer, W.N. Chemical composition and cytotoxic activity of the leaf essential oil of Eugenia zuchowskiae from Monteverde, Costa Rica. J. Nat. Med. 2007, 61, 414-417. [CrossRef]

56. Ait-Ouazzou, A.; Cherrat, L.; Espina, L.; Lorán, S.; Rota, C.; Pagán, R. The antimicrobial activity of hydrophobic essential oil constituents acting alone or in combined processes of food preservation. Innov. Food Sci. Emerg. Technol. 2011, 12, 320-329. [CrossRef]

57. Trombetta, D.; Castelli, F.; Sarpietro, M.G.; Venuti, V.; Cristani, M.; Daniele, C.; Saija, A.; Mazzanti, G.; Bisignano, G. Mechanisms of Antibacterial Action of Three Monoterpenes. Antimicrob. Agents Chemother. 2005, 49, 2474-2478. [CrossRef]

58. Burt, S. Essential oils: Their antibacterial properties and potential applications in foods-a review. Int. J. Food Microbiol. 2004, 94, 223-253. [CrossRef] [PubMed]

59. Imelouane, B.; Amhamdi, H.; Wathelet, J.P.; Ankit, M.; Khedid, K.; El Bachiri, A. Chemical composition of the essential oil of thyme (Thymus vulgaris) from Eastern Morocco. Int. J. Agric. Biol. 2009, 11, 205-208.

60. Nazzaro, F.; Fratianni, F.; De Martino, L.; Coppola, R.; De Feo, V. Effect of Essential Oils on Pathogenic Bacteria. Pharmaceuticals 2013, 6, 1451-1474. [CrossRef] [PubMed]

61. Djerrad, Z.; Kadik, L.; Djouahri, A. Chemical variability and antioxidant activities among Pinus halepensis Mill. essential oils provenances, depending on geographic variation and environmental conditions. Ind. Crop. Prod. 2015, 74, 440-449. [CrossRef]

62. Wang, C.-Y.; Chen, Y.-W.; Hou, C.-Y. Antioxidant and antibacterial activity of seven predominant terpenoids. Int. J. Food Prop. 2019, 22, 230-238. [CrossRef]

63. Wojtunik-Kulesza, K.A.; Kasprzak, K.; Oniszczuk, T.; Oniszczuk, A. Natural Monoterpenes: Much More than Only a Scent. Chem. Biodivers. 2019, 16, e1900434. [CrossRef] [PubMed]

64. Garzoli, S.; Turchetti, G.; Giacomello, P.; Tiezzi, A.; Masci, V.L.; Ovidi, E. Liquid and Vapour Phase of Lavandin (Lavandula $\times$ intermedia) Essential Oil: Chemical Composition and Antimicrobial Activity. Molecules 2019, 24, 2701. [CrossRef] [PubMed]

65. Oliva, A.; Garzoli, S.; Sabatino, M.; Tadić, V.; Costantini, S.; Ragno, R.; Božović, M. Chemical composition and antimicrobial activity of essential oil of Helichrysum italicum (Roth) G. Don fil. (Asteraceae) from Montenegro. Nat. Prod. Res. 2020, 34, 445-448. [CrossRef] [PubMed] 
66. Balouiri, M.; Sadiki, M.; Ibnsouda, S.K. Methods for in vitro evaluating antimicrobial activity: A review. J. Pharm. Anal. 2016, 6, 71-79. [CrossRef]

67. Wang, T.-H.; Hsia, S.-M.; Wu, C.-H.; Ko, S.-Y.; Chen, M.Y.; Shih, Y.-H.; Shieh, T.-M.; Chuang, L.-C.; Wu, C.-Y. Evaluation of the Antibacterial Potential of Liquid and Vapor Phase Phenolic Essential Oil Compounds against Oral Microorganisms. PLoS ONE 2016, 11, e0163147. [CrossRef]

68. Sanchez-Moreno, C.; Larrauri, J.A.; Saura-Calixto, F. A procedure to measure the antiradical efficiency of polyphenols. J. Sci. Food Agric. 1998, 76, 270-276. [CrossRef]

69. Re, R.; Pellegrini, N.; Proteggente, A.; Pannala, A.; Yang, M.; Rice-Evans, C. Antioxidant activity applying an improved ABTS radical cation decolorization assay. Free Radic. Biol. Med. 1999, 26, 1231-1237. [CrossRef] 